Jalan Teuku Umar, Lubuk Baja, Kota Batam-Indonesia Telp. 0778 - 4083113

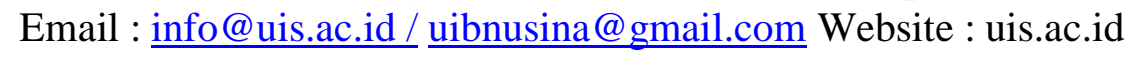

\title{
MENINGKATKAN KEUNGGULAN BERSAING MELALUI HARGA PADA UKM KOTA BATAM
}

\author{
Hendri Herman \\ Manajemen, Fakultas Ekonomi dan Bisnis, Universitas Ibnu Sina, Batam \\ e-mail: hendrihermanbatam@gmail.com
}

\begin{abstract}
Abstrak
This study aims to look at the influence of price in determining the advantages of the cross-legged and how much the influence of price on competitive advantage. The sample in this study was 92 respondents. The result of this study is known that price has a significant influence on the competitive advantage of a company. The amount of price influence on competitive advantage is $43.7 \%$.. This price influence has a considerable influence on the competitive advantage of the company. Therefore, companies or businesses need to special attention in determining the selling price of products
\end{abstract}

Keywords: Price, Competitive Advantage, SMEs.

\section{Pendahuluan}

Terbukanya pasar dalam negeri akibat globalisasi menjadi ancaman yang besar bagi UKM yang ada di Indonesia termasuk di dalamnya usaha ekonomi kreatif. Kondisi ini menuntut perusahaan untuk menempuh langkah-langkah strategic dalam menuju ke masa depan dengan kondisi ketidakpastian lingkungan yang tinggi dan turbulence setelah terjadinya krisis ekonomi. Fakta menunjukkan bahwa meskipun memiliki sejumlah kelebihan yang memungkinkan Usaha Kecil Menengah (UKM) dapat bretahan dalam menahan badai krisis, tidak semua usaha kecil dapat lepas dari akibat buruk krisis ekonomi maupun perubahan yang terjadi pada lanskap abad kedua puluh satu (Khouroh et al., 2019)

Keunggulan bersaing berkaitan dengan cara bagaimana perusahaan memilih dan dapat melaksanakan strategi generik ke dalam praktik. Semua bagian yang ada dalam organsiasi, baik yang berupa sumber daya maupun aktifitas, dapat menjadi keunggulan bersaing. Keunggulan bersaing dapat dilanjutkan melalui penegakan halangan untuk masuk oleh pesaing potensial, seperti skala dan cakupan ekonomi, pengaruh kurva pengalaman atau pembelajaran, diferensiasi produk, persyaratan modal, dan biaya karena berpindahnya pembeli (Porter, 2008) dalam (Herman et al., 2018). Semakin ketatnya persaingan yang dihadapi, perusahaan harus fleksibel, kreatif, dan inovatif, sehingga dalam menghadapi persaingan dengan efektif dan efisien, diperlukan suatu keunggulan kompetiif dari perusahaan yang tidak mudah ditiru, tahan lama, menarik (Paramita, 2015) dalam (Herman et al., 2018). Fenomena (konteks persaingan dan keunggulan bersaing) dapat dimengerti ketika setiap organisasi berupaya mencari strategi bersaing dan basis daya saing yang tepat untuk unggul. Konsep stretegi itu sendiri, seperti didefenisikan Barney (2007) dalam (Herman et al., 2018), adalah berkaitan dengan teori sebuah organisasi bagaimana ia berkinerja tinggi dan unggul dalam bidang bisnisnya. 
Salah satu hal yang perlu dipertimbangkan dalam mempertahankan bahkan meningkatkan keunggulan bersaing di tengah gempuran produk-produk impor dengan harga yang cukup terjangkau ialah pelaku usaha perlu mempertimbangkan harga jual produknya. Tidak dapat dipungkiri jika banyak konsumen yang tertarik dengan produk dengan harga terjangkau. Maka dari itu, kondisi seperti ini dapat menjadi perhatian bagi para pelaku usaha agar dapat terus survive dalam menjalankan usahanya.Harga jual merupakan harga yang ditetapkan oleh pelaku usaha dalam usahanya untuk memperoleh keuntungan dari selisih harga jual dengan biaya produksi.

\section{Kajian Pustaka / Kajian teori \\ 1. Harga}

Menurut Tan $(2011 ; 26)$ dalam (Mandey, 2013) harga ialah jumlah uang yang harus dibayar pelanggan untuk memperoleh produk tersebut. Harga adalah satu-satunya unsur bauran pemasaran yang menghasilkan pendapatan penjualan karena unsur yang lain adalah mengeluarkan biaya. Menurut Hasan (2008:298) dalam (Kodu, 2013) menyatakan bahwa harga merupakan segala bentuk biaya moneter yang dikorbankan oleh konsumen untuk memperoleh, memiliki, memanfaatkan sejumlah kombinasi dari barang beserta pelayanan dari suatu produk. Perusahaan harus menetapkan harga jual untuk yang pertama kalinya, terutama pada saat mengembangkan produk baru. Penetapan harga jual berpotensi menjadi suatu masalah karena keputusan penetapan harga jual cukup kompleks dan harus memperhatikan berbagai aspek yang mempengaruhinya.

Indikator dalam penetapan harga jual :

1) Keterjangkauan harga

2) Kesesuaian harga

3) Daya saing harga

\section{Keunggulan Bersiang}

Keunggulan kompetitif adalah sejauh mana sebuah organisasi mampu menciptakan posisi dimana dapat mempertahankan pasar selama masih adanya pesaing. Perusahaan menciptakan keunggulan kompetitif melalui kemampuan kompetitif atau prioritas yang didefenisikan sebagai preferensi strategis atau dimensi dimana perusahaan memilih untuk bersaing di pasar yang ditargetkan (Russel \& Millar, 2014) dalam (Herman, 2018)

Indikator keunggulan bersaing :

1) Keunikan produk

2) Kualitas Produk

3) Harga Bersaing

\section{Kerangka Pemikiran} berikut:

Adapun kerangka pemikiran dalam penelitian ini dapat digambarkan sebagai 


\section{Hipotesis Penelitian}

Dari kerangka pemikiran di atas, maka hipotesis yang dalam penelitian ini adalah harga memiliki pengaruh signifikan terhadap keunggulan bersaing.

\section{Metode Penelitian}

Penelitian ini merupakan penelitian deskriptif kuantitatif, dimana data yang diperoleh melalui penyebaran kuisioner kepada para responden. Data yang telah diperoleh nantinya akan ditabulasi dan diolah menggunakan software pengolah data SPSS. Analisis yang digunakan dalam penelitian ini adalah pengujian kualitas data, uji normalitas data, uji heteroskedastisitas data, analisis koefisien determinasi dan uji hipotesis. Responden dalam penelitian ini adalah sebanyak 92 responden

\section{Hasil dan Pembahasan}

\section{Uji Validitas Data}

Hasil uji validitas harga dalam penelitian ini dapat dilihat sebagai berikut:

Tabel 1. Hasil Uji Validitas Harga

\begin{tabular}{|l|l|l|l|l|}
\hline No & Item & R hitung & R tabel & Kesimpulan \\
\hline 1 & X.1.1 & 0.650 & 0.2050 & Valid \\
\hline 2 & X.1.2 & 0.653 & 0.2050 & Valid \\
\hline 3 & X.1.3 & 0.845 & 0.2050 & Valid \\
\hline
\end{tabular}

Berdasarkan tabel di atas, dapat dilihat bahwa nilai $r$ hitung masing-masing item dalam variabel harga lebih besar dari nilai $r$ tabel (0.2050). maka dapat disimpulkan bahwa semua item dalam variabel harga adalah valid berikut:

Hasil uji validitas keunggulan bersaing dalam penelitian ini dapat dilihat sebagai

Tabel 2. Hasil Uji Validitas Keunggulan Bersaing

\begin{tabular}{|l|l|l|l|l|}
\hline No & Item & R hitung & R tabel & Kesimpulan \\
\hline 1 & Y.1 & 0.760 & 0.2050 & Valid \\
\hline 2 & Y.2 & 0.756 & 0.2050 & Valid \\
\hline 3 & Y.3 & 0.675 & 0.2050 & Valid \\
\hline
\end{tabular}

Berdasarkan tabel di atas, dapat dilihat bahwa nilai $\mathrm{r}$ hitung masing-masing item dalam variabel keunggulan bersaing lebih besar dari nilai $r$ tabel (0.2050). maka dapat disimpulkan bahwa semua item dalam variabel keunggulan bersaing adalah valid

\section{Uji Reliabilitas}

Tabel 3. Hasil Uji Reliabilitas

Hasil uji reliabilitas dalam penelitian ini adalah sebagai berikut:

\begin{tabular}{|l|l|l|l|}
\hline No & Variabel & Cronbach Alpha & Kesimpulan \\
\hline 1 & Harga & 0.873 & Reliabel \\
\hline 2 & Keunggulan Bersaing & 0.644 & Reliabel \\
\hline
\end{tabular}

Berdasarkan tabel di atas, dapat dilihat bahwa masing-masing nilai cronbach alpha pada variabel harga dan keunggulan bersaing sebesar 0.873 dan 0.644 . nilai cronbach alpha ini lebih besar dari 0.6. sehingga disimpulkan bahwa item-item dalam variabel ini adalah reliabel. 


\section{Uji Asumsi Klasik}

\section{Uji Normalitas} ini:

Uji normalitas dalam penelitian, dapat dilihat pada tabel Kolmogorov berikut

Tabel 4. Hasil Uji Normalitas.

One-Sample Kolmogorov-Smirnov Test

\begin{tabular}{|ll|r|}
\hline & & $\begin{array}{r}\text { Standardize } \\
\text { d Residual }\end{array}$ \\
\hline $\mathrm{N}$ & Mean & 92 \\
Normal & Std. & .0000000 \\
Parameters & Deviation & .97469532 \\
& Absolute & .075 \\
Most Extreme & Positive & .075 \\
Differences & Negative & -.063 \\
Kolmogorov-Smirnov Z & .807 \\
Asymp. Sig. (2-tailed) & .372 \\
\hline
\end{tabular}

a. Test distribution is Normal.

b. Calculated from data.

Dari tabel di atas, dapat dilihat bahwa nilai Asymp. Sig (2 tailed) memiliki nilai sebesar 0.372. nilai signifikansi ini lebih besar dari 0.05, sehingga dapat disimpulkan seluruh data dalam penelitian ini telah terdistribusi secara normal.

\section{Uji Heteroskedastisitas}

Hasil uji heteroskedastisitas dalam penelitian ini dapat dilihat pada gambar scatter plot berikut ini:

\section{Scatterplot}

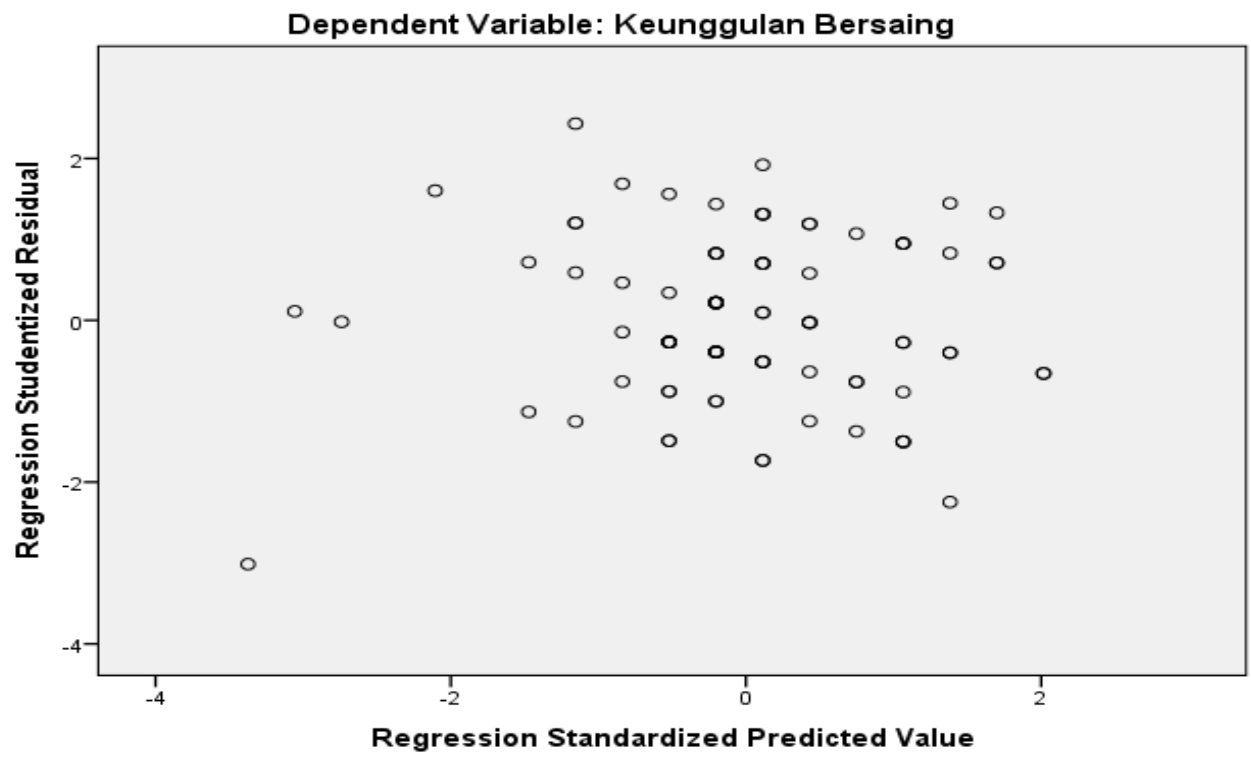


Dari gambar scatter plot di atas, dapat dilihat bahwa titik-titik telah menyebar di atas dan di bawah angka nol (0) pada sumbu Y, dan sebaran titik-titik tersebut tidak membentuk pola yang jelas, sehingga dapat disimpulkan bahwa data dalam penelitian ini tidak terjadi masalah heteroskedastisitas.

\section{Analisis Koefisien Determinasi}

Analisis koefisien determinasi dapat dilihat pada tabel berikut:

Tabel 5. Analisis Koefisien Determinasi

Model Summary ${ }^{b}$

\begin{tabular}{|l|r|r|r|r|}
\hline Model & R & R Square & Adjusted R Square & $\begin{array}{c}\text { Std. Error of the } \\
\text { Estimate }\end{array}$ \\
\hline 1 & $.437^{\mathrm{a}}$ & .453 & .185 & 1.870 \\
\hline
\end{tabular}

a. Predictors: (Constant), Harga

b. Dependent Variable: Keunggulan Bersaing

Dari tabel di atas, dapat dilihat bahwa nilai R sebesar 0.437 atau sebesar $43.7 \%$. Hal ini menunjukkan bahwa harga mampu menjelaskan keunggulan bersaing sebesar 43.7\%, sedangkan sisanya sebesar $56.3 \%$ dipengaruhi oleh variabel lain yang tidak dimasukkan dalam penelitian ini

\section{Uji Hipotesis}

\section{Uji Parsial (Uji t)}

Hasil pengujian hipotesis pada penelitian dapat dilihat pada tabel berikut:

Tabel 6. Uji Parsial (Uji t)

Coefficients $^{\mathbf{a}}$

\begin{tabular}{|c|c|c|c|c|c|}
\hline \multirow[t]{2}{*}{ Model } & \multicolumn{2}{|c|}{$\begin{array}{c}\text { Unstandardized } \\
\text { Coefficients }\end{array}$} & \multirow{2}{*}{$\begin{array}{c}\text { Standardize } \\
\text { d } \\
\text { Coefficients } \\
\text { Beta }\end{array}$} & \multirow[t]{2}{*}{$\mathrm{T}$} & \multirow[t]{2}{*}{ Sig. } \\
\hline & $\mathrm{B}$ & Std. Error & & & \\
\hline (Constant) & 5.154 & 1.030 & & 5.734 & .000 \\
\hline Harga & .531 & .073 & .631 & 2.573 & .005 \\
\hline
\end{tabular}

a. Dependent Variable: Keunggulan Bersaing

Berdasarkan tabel di atas, dapat dilihat bahwa nilai signifikansi variabel harga sebesar 0.005. Nilai signifikansi ini lebih kecil dari 0.05. sehingga dapat disimpulkan bahwa harga berpengaruh signifikan terhadap keunggulan bersaing. Maka hipotesis yang diajukan dalam penelitian ini diterima.

\section{Pembahasan}

1. Harga berpengaruh signifikan terhadap keunggulan bersaing

Harga dalam penelitian ini memiliki pengaruh signifikan terhadap keunggulan bersaing. Hal ini dapat dikarenakan konsumen lebih tertarik terhadap produk yang memiliki harga jual yang terjangkau tanpa mengabaikan kualitas produk itu sendiri. Masyarakat akan tetap setia menggunakan produk, membeli produk jika produk tersebut dapat dibeli dengan harga yang terjangkau. Maka dari itu, perusahaan perlu memberikan perhatian khusus dalam menetapkan harga jual 
produk. Penetapan harga jual produk ini perlu mempertimbangkan kelangsungan perusahaan demi memenangkan persaingan dengan perusahaan yang sejenis. Dalam berbisnis, tentu pihak perusahaan ingin mendapatkan keuntungan yang besar, keuntungan tersebut dapat ditentukan oleh harga jual yang ditetapkan oleh perusahaan. Maka dari itu, agar produk tetap diminati dan laku di pasaran, maka penetapan harga jual produk perlu menjadi pertimbangan penting bagi perusahaan.

\section{Simpulan} berikut:

Berdasarkan hasil penelitian ini, maka dapat diambil kesimpulan sebagai

1. Harga berpengaruh signifikan terhadap keunggulan bersaing

2. Harga memberikan pengaruh sebesar $43.7 \%$ terhadap keunggulan bersaing. Pengaruh harga terhadap keunggulan bersaing cukup tinggi. Maka dari itu, penetapan harga jual perlu menjadi perhatian khusus oleh pelaku usaha

\section{Daftar Pustaka}

Barney, J. B. (2007). Gaining and Sustaining Competitive Advantage. Pearson Prentice Hall.

Herman, H. (2018). Strategi Meningkatkan Keunggulan Bersaing Melalui Kualitas Pelayanan Pada PT Putra Usaha Mandiri Kota Batam. Jurnal Akuntansi Barelang, 3(1), 57-63.

Herman, H., Hady, H., \& Arafah, W. (2018). The Influence of Market Orientation and Product Innovation on the Competitive Advantage and Its Implication toward Small and Medium Enterprises (Ukm) Performance. International Journal of Science and Engineering Invention, 4(08), 8-21. https://doi.org/10.23958/ijsei/vol04-i08/02

Khouroh, U., Abdullah, F., \& Handayani, K. (2019). Keunggulan Bersaing Berkelanjutan UKM Ekonomi Kreatif. Uwais Inspirasi Indonesia.

Kodu, S. (2013). Harga, Kualitas Produk dan Kualitas Pelayanan Pengaruhnya Terhadap Keputusan Pembelian Mobil Toyota Avanza. Jurnal EMBA, 1(3), 12511259.

Mandey, J. B. (2013). Promosi, Distribusi, Harga Pengaruhnya Terhadap Keputusan Pembelian Rokok Surya Promild. Jurnal EMBA, ISSN: 2303-1174, 1(4), 95-104.

Paramita, C. C. (2015). Pengaruh Kompetensi Individu, Orientasi Kewirausahaan, dan Pesaing dalam Mencapai Keunggulan Bersaing Melalui Kualitas Produk. Studi Pada UKM Furnitur di Kota Semarang. DeReMa Jurnal Manajemen, Vol. 10(1). Porter. (2008). Competitive Advantage. Karisma Publishing Group. 